\title{
BRIEF COLLECTION HISTORY OF THE HABAN CERAMICS IN THE MUSEUM OF APPLIED ARTS IN THE LIGHT OF HABAN RESEARCH
}

\author{
Gabriella BALLA \\ Museum of Applied Arts \\ Üllői út 33-37, 1091 Budapest, Hungary \\ E-mail: ballagabr@gmail.com
}

\begin{abstract}
The Museum of Applied Arts has the richest collection of Haban ceramics of any public collection in Hungary. The museum preserves close to four hundred items of Haban ceramics made before 1760: vessels, stove tiles, a stove and floor tiles. The article presents the history of the collection with special regard to the aims of the collecting, the circumstances of acquisitions and the most important collectors. It cites the thought of Jenő Radisics, the director general who has made the greatest contribution to the museum, on collection building that can be regarded as the most up-to-date museum conception at the turn of the $19^{\text {th }}$ to the $20^{\text {th }}$ century, particularly because his ideas laid the foundations for the $21^{\text {st }}$ century philosophy of museums. These Haban ceramics intended for the use of aristocrats also served as a material relic of the national consciousness of European nation-states.

Keywords: Haban ceramics, $17^{\text {th }}$ century, Museum of Applied Arts, Budapest, Jenő Radisics, ethnography and applied art, collection building, private Haban collectors, exhibitions of Haban ceramics
\end{abstract}

Antecedent of this article was the paper presented at the conference held in the Hungarian National Museum on Haban relics in Central European archaeological finds and collections on $25^{\text {th }}$ of October 2011. It attempted to present with a large number of images, the collection of the Museum of Applied Arts, the largest Haban public collection in Hungary in view of the nature of the event and the participants. The museum's collection of Haban objects comprises close to four hundred items. The great majority of the ceramic objects made before 1760, three hundred items, are vessels. The remaining eighty-two items are stove tiles, one item is a stove, ${ }^{1}$ and fourteen items are floor tiles. The series of publications of the last twenty-five years on this topic, namely the examination and overview of the museum's collecting activity began with a study by Márta Péter titled: Collecting History Sketch (PÉTER 1988: 11-18), for which the author of the volume, István Bardoly, compiled a basic bibliography (PÉTER 1988: 18-19). Numerous publications by

${ }^{1}$ For the most recent scholarly publication on the museum's Haban stove and collection of stove tiles, see: RADVÁNYi 2013: 57-70. 
Hilda Horváth also contain data mainly on the museum's collecting history but also on collectors and collections connected in some way to the Museum of Applied Arts; they also refer to the collecting history of its Haban objects (HoRvÁth 2000, 2006: 21-94). The preparations for the exhibition held in the Museum of Applied Arts on Haban objects in Hungarian private collections "Haban Myth 1593-1738: Treasures of Hungarian Private Collections" Budapest, 21 May-25 November 2007, curated by and catalogue edited by Dr. László Réti, drew attention to the urgent need for research on Haban ceramics. In his opening speech, the director general of the museum promised to take the initiative for such scholarly research.

In the period since the conference, the ongoing OTKA-funded Haban research ${ }^{2}$ has further developed earlier thoughts on the collection. Many new considerations have arisen, leading to further questions especially concerning the formation and expansion of the museum collections, in our case with special regard to the applied arts collections of Hungarian relevance. A number of questions in need of further thinking and analysis have been raised. Why and when did particular object groups become especially interesting? How did they come to be in the focus of attention? What were the social or political promptings that led to this interest? How does the scholarly study and exhibition activity of museums increase the historical or cultural historical value of these objects? Has the art object trade and private collecting had and does it have an influence on museums? How can the influence and role of scholarly research and museums in these processes be examined?

The present article can only provide a partial answer to these questions, nevertheless in presenting the collection it aims to throw a sharper light on the picture we already know and this can best be achieved by following the chronological order.

In examining the initial period in formation of the collection and laying of theoretical foundations, it is important to dwell at some length on the lines written a hundred years ago by Jenö Radisics ${ }^{3}$ (1856-1817), the director general of the Museum of Applied Arts, who has left the most important oeuvre. In them, he very precisely defines not only the main guidelines for collecting and collection building, but also the typical social phenomena that appear in all periods as expectations regarding museums.

"The initiatives arising from enthusiasms that appear from time to time in Hungarian public life are generally very short-lived. They are ephemeral, born from the ray of sunshine of a thought and fading away in the dusk of indifference. The cause of this constantly recurring phenomenon is that the initiative is generally not motivated by the constraint of necessity but rather by a sudden idea and even more often by an idea that has come from abroad. But when an initiative has been brought to fruition by a need, its future is ensured. That is why the Museum of Applied Arts still exists today, has flourished, and is constantly developing.

The second World Exposition held in London in 1862 gave birth to it, its nurse was the National Association of Industry, its foster father was the former Ágoston Trefort, minister

\footnotetext{
${ }^{2}$ Hungarian Scientific Research Fund, OTKA-funded research began in 2010 with the aim of bringing together, including in a database and systematising the Hutterite, Haban ceramics in public and private collections in Hungary. (OTKA K81201, K81213 and K81133).

${ }^{3}$ Jenö Radisics was an associate of the museum from 1881 and from 1897 up to his death he was director general of the institution.
} 
for religion and education. It spent its childhood years in the basement of the old Kunsthalle, not under the best of conditions. It entered manhood in the year of the celebration of the national millennium when, thanks to the country, whose support for it was won by the former Count Albin Csáky, minister for education at that time, it was given a new home in the palace in Üllöi Street, imbued with the artistic spirit of Ödön Lechner. [...]

All the world's museums of applied arts began with the same programme: to bring together in a collection the characteristic and most outstanding relics of applied art of the past and, using them as teaching material that through its conceptual content is able to guide and to revive long-forgotten techniques, to develop the applied arts of our age, increase their competitiveness, preferably to such a level that they eliminate foreign imports, and at the same time refine public taste and increase the love of works of art so that the public become buyers of Hungarian products aspiring to art. We too have set ourselves these tasks. What and how much of its programme the museum was able to realise then depended everywhere on the means available and the conditions." (RADISICS 1915: 117)

Art historian Márta Péter (1940-1991), deputy director general of the Museum of Applied Arts was the initiator and up to her death curator of the museum's series of exhibitions on style history. ${ }^{4}$ From a distance of around a hundred years, she evaluated museum collection building as follows: "There is always a tension between systematic acquisitions and the randomness of the offer in the collecting activity of museums that is determined by the social prestige of the institution at the given time and its resulting possibilities, and by the professional preferences. It is not likely that within that frame the holdings of art objects representing different style periods have a separate history.” (PÉTER 1988: 11)

At the same time it is important to note that ever since the establishment of the museum, objects of Hungarian relevance have enjoyed absolute priority, both in collection building and in acquisitions.

Radisics wrote with firm conviction in this connection: "My first aspiration is that the museum should be Hungarian and national, that our country should be predominant. My every effort is directed at ensuring that visitors leave with the feeling of having spent time in a familiar place where they are at home, and that they have seen something that cannot be found anywhere else than in Hungary. Taking this into account, I will first collect in one place everything that is Hungarian, regardless of the material. I am convinced that when the old painted ceiling, as well as the stove, the pot, ${ }^{5}$ fabric, embroidery, jewellery, book bindings and honey cake mould, in short, every single one of the relics of the old artistic industry created in our country are brought together under the same roof, it will be impossible to deny that they are all imbued with a definite, unmistakable, original spirit." (RADISICS 1897: 27) Reading Radisics's thoughts, it is important to stress that these lines

\footnotetext{
${ }^{4}$ The plan and basic arrangements for the series of exhibitions took shape during the period when Dr. Pál Miklós (1927-2002) was director general (he headed the institution from 1975-1985). In the five exhibitions (Renaissance and Mannerism, 1988-1990; Baroque and Rococo, 1989-1991; From Classicism to Biedermeier, 1990-1991; Historicism and Eclecticism, 1992-1997; Art Nouveau - The Dawn of the 20th Century, 1996-2002) the museum presented its most outstanding works of art and masterpieces. This was undoubtedly the most significant professional and exhibition undertaking in the institution's $20^{\text {th }}$ century history; the museum's digitisation programme is now being built on it.

${ }^{5}$ I.e.: ceramics
} 
were written around the time of the millennium of the Hungarian Conquest (1896). They belong to the mentality that imbued the concept of nation, its origin, history, culture, art, style, and in general all its manifestations and that focused attention on research into the subject and then its manifestation in various forms. ${ }^{6}$

The first exhibition presenting the Museum of Applied Arts' Haban collection was held in the Hungarian Room (Fig. 1) of the building in Üllöi Street designed by Ödön Lechner and officially opened by Francis Joseph I, apostolic king of Hungary on 25 October 1896, in the year following the opening. The painted wooden church furnishings had been set up earlier in 1896, in the room created on the first floor of the wing facing Högyes Endre Street ${ }^{7}$. The original plans of the building had provided for the installation of the wooden ceilings and gallery, consequently in addition to their art historical significance, they are also relics of museum history and "museum topography".

The painted wooden ceiling and gallery (1724) of the Calvinist church in Sóly, Veszprém County and the 75 coffers of the painted wooden ceiling (1766) from the Calvinist church in Maksa, Háromszék County (now Macşă, Romania) can still be seen today. ${ }^{8}$

The Hungarian public could see objects of applied art from Hungary set up as a permanent exhibition in the Hungarian Room. Most of the objects displayed in the cases were ceramics. A few textiles hung on the walls. The room's furniture was made in the factory of the cabinetmaker entrepreneur Endre Thék in the Józsefváros district of Budapest (VÁMOS-Lovay 2006: 19), following a brilliant design. The finely executed, well proportioned pieces were also very practical and functional. ${ }^{9}$

In the horizontal display cases with turned legs, the shelves were arranged in pyramid form and provided an excellent place for the ethnographic ceramics collection, Holics and Tata faience and the collection of Haban objects, all arranged in groups. These pieces were among the first to be transferred to the collection of the Museum of Applied Arts from the "ethnological" department and the collection of antiques in the Hungarian National Museum under the direction of Ferenc Pulszky. Pulszky "was the leaven of Hungarian public life [...] he effectively supported the Hungarian applied arts movements" (HoRvÁTH 1997:70-74, 2006: 24) .

On the photograph taken of the exhibition, a strikingly white dish with an especially wide rim and a deep well can be clearly identified in the centre of the bottom row. Coats of arms can be seen in the interlinked wreaths of leaves - a rampant unicorn and a pelican feeding its young with its own blood. The inscription around them reads: NEMES

${ }^{6}$ The Museum of Ethnography's 2005 exhibition and catalogue: József Huszka, the Draughtsman Collector: ed. FEJös 2006), made a very important contribution to evaluation of the phenomenon.

${ }^{7}$ In 1897 it was still called Rákos Street

${ }^{8}$ On church furniture, see: SEMSEY 2012: 7-22 and http:/gyujtemeny.imm.hu/gyujtemeny/festett-famennyezet-a-maksai-reformatus-templombol/2910\#sthash.b7iYb6hP.dpuf. For further images of the objects, see: The Museum of Ethnography's database: Painted wooden ceilings, wooden church furniture in public collections maintained by the state and by churches - http://nmimm-katalogus.hu.

${ }^{9}$ Installations that have been used for close to 120 years have themselves become exhibition objects and are still in the museum today. 
ISKHAZY HORVATH MIKLOS SANDOR SUSANNA:1678:10 [Noble Miklós Horváth of Iskházy and Zsuzsanna Sándor]. (Fig. 2) Another item of exceptional quality among the more than fifty Haban objects transferred from the National Museum is a fluted jug with three flowering plants on the side and the date 1656 (Fig. 3); it came from the collection of Ágoston Szalay (1811-1877), who was a law trainee under Miklós Jankovich, the learned art collector (1772-1846). On the right side of the upper shelf in the display case in the Hungarian Room is a rectangular liquid container with a pewter lid. The painted object with a blue ground and the date 1653 (Fig. 4) is one of the pieces in the exceptional collection sold to the Statewide Hungarian Museum of Applied Arts by Count Jenö Lázár (1850-1904) (HoRváth 2006: 38-39, No. 35). Apart from the Haban faience and glass objects, the collection of jugs purchased by the museum comprised mainly German salt glaze stoneware vessels. Thanks to the collector's grandson, Béla Lipthay, or more precisely due to the difficult situation of the impoverished aristocratic family, in 1953 the Archive of the Museum of Applied Arts came into possession of the album in which one of the descendants of Count Jenő Lázár had painted pieces from the count's collection, in a few cases noting also the place where the objects were collected. The album, ${ }^{11}$ bound in brown leather with the title in gold letters on the cover "Copies of the Megyesfalva" former Jug Collection" was accompanied by the following letter: "H. National Museum Museum of Fine Arts Budapest IX. Üllöi utca 33-37.

Re: Your letter no. 863/0174/953. I infinitely regret that I am able to reply only with such a delay. I returned home yesterday from a trip and found your letter here. I am sending the album concerned with today's mail. My grandfather (Count) Jenő Lázár was born in 1850 in Megyesfalva where his family had an estate. During his life he dealt mainly with the arts and natural sciences and in particular with questions of ornithology (among others, he had friendly relations with Brehm ${ }^{13}$ ). Some fine wood carvings have come down from him. He collected paintings, porcelain objects, pewter jugs (I still have some of the rest in my possession), homespun pieces (some of them are in the Museum of Fine Arts, offered for sale, Edith Fél), fine furniture and the stoneware jugs mentioned. He donated the latter to the Museum of Fine Arts, ${ }^{14}$ but first painted them. The album I am sending was a beloved memory of him in our home. ${ }^{15}$ He died in 1904. For this reason we are parting with this album only because we need the money. I would be very grateful if we could receive the requested 400 Forints as soon as possible, because we are in the greatest need of this sum. I have marked on the parcel the sum of 1000 Forints as the value of the contents only to bring it closer to the real value. I occasionally come to Pest (I am a museum

\footnotetext{
${ }^{10}$ RADVÁNYI - RÉTI 2011: cat. no 202. Earlier the dish was thought to have been a piece made on the occasion of a marriage. István Hermann identified the marriage of the deputy lieutenant of Alsóiszkáz in Veszprém County and Zsuzsanna Sándor that took place in 1653; the date on the bowl indicates that it was probably made for their silver wedding anniversary. See: Hermann 2003: 37-55, and http:/gyujtemeny.imm.hu/gyujtemeny/ tal-cimerparral/1810\#sthash.Qnj8EdWG.dpuf.

${ }^{11}$ Archive of the Museum of Applied Arts KRTF 19. $33.5 \times 50.4 \times 6 \mathrm{~cm}$

${ }^{12}$ Meggyesfalva, Maros County (Muraşeni, Romania) [name variants: Mediesfalva, Medgyesfalva, Megyesfalva].

${ }^{13}$ Alfred Edmund Brehm (1829-1884).

${ }^{14}$ The museum acquired the collection through a purchase.

${ }^{15}$ Odescalchi 1987.
} 
office-bearer), generally on matters of natural science exhibitions and so if I can be of help to you in any other way I am at your disposal. Szécsény, 1953. V/7. Ady E. u. 7. Béla Lipthay." "16 From this rich collection it is worth presenting a Haban piece on a yellow base with a broad band of acanthus leaves on the belly and the date, 1650 (Fig. 5) and another with a flowering plant on a white base, dated 1659 (Fig. 6) together with the corresponding watercolours. (Fig. 7)

In 1888 Baron József Bálintitt of Nagyernye ${ }^{17}$ offered to the museum his collection of ceramics (HoRvÁTH 2006: 39), faience and porcelain objects, including Haban pieces. Among the objects, the Haban material was enriched with a rare form: an apothecary's vessel decorated with a carnation plant, dated 1659. (Fig. 8)

A number of Central European public collections and a few private collections regard the hexagonal and triangular floor tiles painted with a tin glaze as being Haban relics. They are represented in greatest number and - what is especially noteworthy - in a variety of technical execution, in the collection of the Museum of Applied Arts. ${ }^{18}$ The tiles were found in 1907 in Farkashida (Vlčkovce, Slovakia, earlier Farkašin, German: Farkaschin, Wolfsbruck) near Nagyszombat (Trnava, Slovakia, German: Tyrnau), in a cellar the ceiling of which collapsed when a house was being demolished. (Fig. 9)

The museum purchased the faience tablet of the Nagylévárd (Vel'ké Leváre, German: Gross-Schützen, Slovakia) potters' guild from István Gajdács for 500 crowns in 1911. The guild tablet portrays the tools of the craft, a potter's wheel and smoothing knives arranged symmetrically, and beneath them two potters greeting each other. The inscription reads: 1732 / In Ewigkeit. Gelobt sei Jesus Kristus / SALAUS. DEOGRATIAS: /KRATUA [gra-

${ }^{16}$ Baron Béla Lipthay of Kisfaludi and Lubelle was born on 28 May 1892 in Lovrin in the Banat region, the son of an aristocratic family. He was educated in Vienna and Zurich. He served on the front during the First World War. On 30 November 1918 he married Eugenie Odescalchi. From 1920 he devoted his spare time to the scientific study of butterflies and later deepened his knowledge, travelling around the Banat region and the high mountain areas of the Southern Carpathians. In the course of his scientific work he built up an extensive network of international contacts and compiled a collection of 40,000 items. In 1944 he moved with his family to Hungary and purchased the Forgách mansion in Szécsény. In 1950 he took employment in the Palóc Museum in Balassagyarmat. Here he enlarged his butterfly collection to 60,000 items and also studied agricultural entomology. He accumulated a paleobotanical collection of 1200 items, an activity that was linked to the excavation of the Ipolytarnóc finds. From 1968 until his death on 16 March 1974 he continued his activity in retirement.

${ }^{17}$ Nagyernye, Maros County (Ernei, Romania, German: Arn)

${ }^{18}$ The Museum of Applied Arts currently possesses 456 hexagonal floor tiles, 56 triangular tiles and 54 fragments. In recent years art historian Éva Csenkey has researched their origin. With an additional contribution by Szabolcs Serfözö, art historian - "The perspective ornamentation of the floor tiles can be traced back to Italian influence: in the collection of Christ Church College, Oxford there are two drawings - by Leonardo da Vinci or his pupil, Francesco Melzi, around 1515 - that can be regarded as a precise plan for the paving. Publ.: Carlo Pedretti: The Genius of Leonardo da Vinci: His life and work. Pennsylvania, 1975. Leonardo's illustrations drawn for the tract De divina proportione (Venice, 1509) by the Milanese Franciscan monk and mathematician could have served as the model for the geometrical pattern, for example the axonometric drawings showing regular bodies (p. 20)". (http:/gyujtemeny.imm.hu/gyujtemeny/padlocsempek-un-leonardocsempek/2524\#sthash.wbXaMAsD.dpuf) Research on these especially significant ceramics has not yet been concluded. The most recent publication on them is: Recht - Périer-D'Leteren - Griener, 2007, 212. Nr. XI.1. (with an erroneous inventory number). 
dum?] MAG. DIE 23 JULI. ${ }^{19}$ The guild tablet is thus at the same time also a commemorative tablet, recording the return of a journeyman from his travels and his acceptance as a master - on the right is the returning journeyman carrying on his shoulder a bundle tied to his sword, on the left the guild master - and the exact date of the event. (Fig. 10)

In 1917 one glass and four faience objects (CSÁNYI 1917: 231-235) were added to the Haban collection following the purchase of the applied arts collection of Dr. Emil Sigerus of Nagyszeben (Sibiu, Romania, German: Hermannstadt). Earlier Sigerus had collected ethnographical and folk art objects, mainly in the vicinity of Nagyszeben; in 1885 he donated those to the "ethnographical museum of the Transylvanian Carpathian Association". ${ }^{20}$ One of the finest pieces among Sigerus's Haban objects is a blue jug with a lace decoration. (Fig. 11)

In 1919 Károly Csányi, architect, art historian, lecturer at the university of technology (1873-1955) reported that the museum's collection of ceramics was displayed in the Ushaped gallery on the first floor. He mentioned the Haban ceramics in the following words: "Splendid pieces of Hungarian folk ceramics, of which the Haban faience pieces are of outstanding value, are exhibited in the adjoining corridor. The Habans, or Anabaptists migrated to our country in the early $17^{\text {th }}$ century, bringing with them their technique of faience making (tinglaze). Our oldest piece is marked with the date 1606." ${ }^{21}$ In the interwar years, the Haban collection was not significantly expanded. Act XIX of 1922 set up the National Hungarian Universal Collection and its council that functioned up to 1934 by amalgamating five institutions: the National Archive, the Hungarian National Museum, the Széchényi Library that at that time operated within the frame of the National Museum, the Museum of Fine Arts, the Museum of Applied Arts, and the Pázmány Péter University with its library (HoRvÁTH 2006: 71). The prolonged economic crisis that afflicted Hungary did not favour museum affairs. In 1934 the Universal Collection lost its autonomy and jurisdiction over the institutions was then exercised by the council of the Hungarian National Museum.

After the war, in 1946 it was again proposed that the institution should be independent and this was achieved in 1948. During those years, the collection of the Museum of Applied Arts expanded substantially. At the initiative of director Pál Voit, an agreement was reached in the same year between the Museum of Applied Arts and the Hungarian Royal Palatine Joseph University of Technology and Economics ${ }^{22}$, that the art collection of the Department of Chemical Technology established by Vince Wartha that had been

\footnotetext{
${ }^{19}$ Most recent publication: Budapest 2007, 82. cat. no. 147. Habán mítosz [Haban myth], 2007. p. 82. Cat. 147. Translation of the text: "[glory be to Jesus Christ the Saviour and Merciful God for ever and ever Kreistuff: Mag: $23^{\text {rd }}$ day of July]"

${ }^{20}$ Csányi 1917: 231. Csányi ibid. p. 231. The collection is currently the Muzeul de Etnografie şi Artă Populară Săsească "Emil Sigerus"; its most recent scholarly publication: RoşCA - KLusch 2010. Roşca, Carla Klusch, Horst: Ceramica de breaslă, habana si manufacturier ${ }^{\text {s̆ }}$ din Transilvania. Sibiu, Honterus, 2010.

${ }^{21}$ Múzeális ügyek. [Museum Affairs] Magyar Iparmüvészet 1919, 1-2, pp. 36-41. The date 1606 can be seen on an upright rectangular vessel used to hold water; this is the earliest painted piece with a date in the collection. It was transferred from the National Museum to the Museum of Applied Arts in 1877, height: 20 cm. Inventory number: 2846.

${ }^{22}$ It was reorganised as the Budapest University of Technology under Act XV of 1949 of the Council of Ministers.
} 
entirely closed to the public, was to be transferred from the university to the museum. The enormous collection of glass and ceramics was divided among four museums, according to their collecting scope - the Museum of Applied Arts, the Hopp Ferenc Museum of East Asian Arts, the Museum of Ethnography and the Museum of Fine Arts. At present we have thirty-one Haban and late Haban items from the former museum of technology collection. (Fig. 12) Our last multiple acquisition of Haban items came in 1969 from the former collection of art dealer István Fehér. Unfortunately, we have no information on the history or origin of these very high quality pieces (HoRvéth 2006: 85-86). (Fig. 13) A number of well known collectors or persons, whose collecting considerations should be the object of future research, have contributed individual objects to our collection through gift or purchase. ${ }^{23}$ A number of outstanding donors figure among the names. One is Zsigmond Bubics Bishop of Kassa (Košice, Slovakia), who laid the foundations of the Hungarian Baroque faience collection with his generous gift; another is the founder and first director of the museum, György Ráth. Their merits in the history of the museum and of Haban collecting will never fade. When the research is completed, a digital database and a detailed catalogue will link them to the objects that reached the museum through them.

Special mention must be made of Béla Krisztinkovich (1887-1969), ${ }^{24}$ an outstanding figure in the $20^{\text {th }}$ century history of ceramic art collecting in Hungary. He was able to pass on his approach to collecting so effectively that fourth-generation descendants are now following the path he traced. His tertiary studies were in the technical field of architecture, he had a diploma of engineering. He committed himself to the arts at an early age. $\mathrm{He}$ was a founding member of the Saint George Guild Association of Hungarian Amateurs and Collectors ${ }^{25}$ founded in 1909 and grouping art collectors and art lovers. Between 1912 and 1920 this association published a journal $A$ Gyüjtö [The Collector] that also presented important Hungarian private collections. In the company of and under the influence of the Saint George Guild's chairman Dr. László Siklóssy, as well as of fellow collectors - Károly Hatvany, Mór Herczog, Frigyes Glück, Nándor Baumgartner, Ödön Wildner, Ödön Faragó, Titusz Babes and others - Hungarian ceramics soon became the focus of his attention. In

${ }^{23}$ Gusztáv Adler, Ferenc Alm, István Batlits, Ignác Bizamir, Max Blum art dealer, Zsigmond Bubics Bishop of Kassa, Mrs Péter Czigány, Mrs István Dancs, János Dávid, Frigyes Deutsch, Ödön Eisenstädtner, Mrs Dezső Fekete, Ignác Friedmann, A. Fuchs, Dr. Árpád Gyergyai, Dr. Henrik Herz, Dávid Kaiser, Jenő Karragits, Dr. Mrs Tibor Keresztes, Mrs László Keresztessy, Mária Kövér, János Lakos, Mrs. Lajos Landerer, Manó Lessner, Mrs Manó Lessner, József Lipcsey, Zoltán Máriási, László Mauthner art dealer, Lajos Meller architect, Simon Meller, Gyula Mihalik teacher, Endre Morvai, Gusztáv Mühl, Dr. Mrs József Nagy, Mrs Lajos Nagy, Baron Jenő Nyáry, Mrs Gyulá Pekár, György Palkovics, Péter Pap, István Petróczy, József Pécsi, Mór Pick art dealer, Kálmány Pogány, Mrs Béla Procopius née Veronika Solymosy, Mór Pscherhoffer, Mrs Ferenc Pulszky née Terézia Walter, György Ráth, Mrs György Ráth née Gizella Melcsitzky, Adolf Resch, Béla Révay, Dr. Ágnes Sallér, Sámuel Schwarz, Gábor Schpitz, Károly Sédi, Zsigmond Steiner, Klára Strasser, Gyula Szányi, Dr. Mrs Dezső Szász, Sztehló, Mrs Vilmos Tarcsay, Irma Telegdy Róth, István Thuránszky, Ferenc Tóth, Mrs Tivadar Uray, Dr. Mrs Zoltán Végh, Mrs József Vörös, Dávid Weiss, József Wolf, József Záhora, Ede Zeményi, Mrs Sámuel Ziegler. This list was compiled from the digitised version of the Museum of Applied Arts' main inventory, based on the present state (October 2014).

${ }^{24}$ His life history was written by his daughter Mária Krisztinkovich on the basis of his autobiography, KRISZTINKOVICH 2005.

${ }^{25}$ Vasné Tóth, Kornélia: A Nap szint ad a virágnak, a Müvészet az Életnek [The Sun gives colour to the flower, and Art gives colour to Life]. In Kisgrafika 2013/2, 3. 
his autobiography he mentions that his commitment to Hungarian ceramics deepened in the course of his friendship and conversations (from 1910) with Jenő Farkasházy Fischer, director of the Herend factory (KRISZTINKOVICH 2005: 34). The world of Haban ceramics was one of the major areas of his interest in ceramics. He sought and maintained contacts with fellow collectors, archaeologists, art historians, ethnographers, he visited numerous European museums, and through his personality these contacts soon grew into friendships. He published the findings of his research in journals and many of his conclusions are still valuable points of reference for further research. The reason his memory is briefly evoked here is not that a large number of objects entered the Haban collection of the Museum of Applied Art from the art collection of Béla Krisztinkovich, ${ }^{26}$ but that the museum is aware of and highly values the collecting activity carried out by him and his descendants. In the difficult situation following the Second World War the family was obliged to part with a few pieces. The round-bellied painted jug with the date 1640 and a pewter lid entered the collection of the Museum of Applied Arts in 1972; decorated with strong, dark colours and a dynamically spiralling acanthus branch with leaves, berries and fruit, it is an object of high quality and a worthy memorial to the collector. (Fig. 14)

\section{LITERATURE}

CSÁNYI Károly

1917: Sigerus Emil gyüjteménye [The Collection of Emil Sigerus]. Magyar Iparmüvészet, 231-235.

FEJős Zoltán (ed.)

2006: Huszka József, a rajzoló gyüjtő [József Huszka, the Collector Draughtsman]. Ed.: FEJös Zoltán. Museum of Ethnography, Budapest, [Exhibition catalogue].Habán mitosz 1593-1738: Magyar magángyüjtemények kincsei [Haban Myth 1593-1738: Treasures of Hungarian Private Collections]. Budapest, 21 May-25 November 2007, the exhibition was curated and the catalogue edited by Dr. László RÉTI.

Hermann István

2003: Sándor Zsuzsanna végrendelete 1688-ból. [The Will Made by Zsuzsanna Sándor in 1688]. Acta Musei Papensis. Pápai Múzeumi Értesítö, 8, 37-55.

HoRvÁTH Hilda

1997: Pulszky Ferenc és az iparmüvészeti mozgalmak [Ferenc Pulszky and the Applied Arts Movements]. In Pulszky Ferenc (1814-1897) emlékére [In memoriam Ferenc Pulszky (1814-1897)]. Eds: LACZKÓ, Ibolya - SzaBó, Júlia - TóThné MészÁRos, Lívia. Budapest, 70-74.

2000: Iparmüvészeti Kincsek Magyarországon: Tisztelet az adományozónak [Applied Arts Treasures in Hungary. Tribute to the Donors]. Budapest, Athenaeum 2000 Kiadó.

2006: Az Iparművészeti Múzeum mügyüjteményének története - Vázlat [History of the Art Collection of the Museum of Applied Arts - Outline]. In: Az idö sodrában: Az Iparmüvészeti Múzeum gyüjteményeinek története [History of the Collections of the Museum of Applied Arts]. Ed.: PATAKI, Judit. Budapest, Museum of Applied Arts, 21-94.

KRISZTinkovich Maria

2005: Béla Kriszinkovich (1887-1969). In J. Eugene Horváth - Maria H. Krisztinkovich: A History of Haban Ceramics a Private View. Canada, Vancouver, 33-40.

${ }^{26}$ Béla Krisztinkovich's descendants continue to care for and enrich the collection with great devotion. The public was able to see the finest pieces in the collection in the exhibition titled Haban Myth held in 2007. See: RÉTI 2007. 
OdesCAlCH Eugénie

1987: Egy hercegnö emlékezik [A Princess Remembers]. Budapest, Gondolat Kiadó. PÉTER Márta

1988: Gyüjtéstörténeti vázlat [Collection History Sketch]. In: Reneszánsz és manierizmus: Kiállítás az Iparmüvészeti Múzeum gyüjteményéböl [Renaissance and Mannerism: Exhibition from the Collection of the Museum of Applied Arts]. Budapest, Museum of Applied Arts, Catalogue I. Texts. Ed.: BARDOLY István. Curator of the series of exhibitions on style periods in European applied art and editor of the catalogues: PÉTER, Márta. Budapest, 11-18.

RADISICS Jenö

1915: Az Orsz[ágos]. Magy[ar]. Iparművészeti Múzeum és magyar gyüjteménye [The National Hungarian Museum of Applied Arts and its Hungarian Collection]. Magyar Iparmüvészet. 117-136.

1897: Az Orsz[ágos]. Magy[ar]. Iparmúvészeti Múzeum. [The National Hungarian Museum of Applied Arts]. Magyar Iparmüvészet 1, 26-30.

RADVÁNYi Diána - RÉTI László

2011: A habánok kerámiamüvészete [The Ceramic Art of the Habans]. Budapest, Novella, A Kárpátmedence kerámiamüvészete IV. [Ceramic Art of the Carpathian Basin IV]. Series editor: VöRösvÁRY, Ferenc.

2013: Fayencekachelöfen der Habaner, Ofenkacheln und ihre Rekonstruktionen in der Sammlung des Kunstgewerbemuseums zu Budapest. Ars Decorativa 29, 57-70.

Recht, Roland - Périer-D’Leteren, Catheline - Griener, Pascal

2007: The Grand Atelier. Pathways of Art in Europe, 5th-18th centuries. Palais des Beaux-Arts, Brussels, Brussels.

RÉTI László (ed.)

2007: Habán mitosz. 1593-1738. Magyar magángyüjtemények kincsei [Haban Myth 1593-1738. Treasures from Hungarian Private Collections]. Exhibitive Catalogue of the Museum of Applied Arts. Budapest, 1-84.

Roșca, Carla - Kuusch, Horst

2010: Ceramica de breaslă, habana şi manufacturieră din Transilvania. Sibiu, Honterus, 2010.

Semsey, Balázs

2012: Architecture and Museology at the End of the 19th Century. The "Hungarian Room" of the Museum of Applied Arts. Ars Decorativa 28. Ed.: PréKopa, Ágnes. 7-22.

VÁmos-Lovay Zsuzsanna

2006: Az Iparmúvészeti Múzeum berendezései [Furnishings of the Museum of Applied Arts]. In: Az idö sodrában: Az Iparmüvészeti Múzeum gyüjteményeinek története [History of the Collections of the Museum of Applied Arts]. Ed.: Pataki, Judit. Budapest, Museum of Applied Arts. 


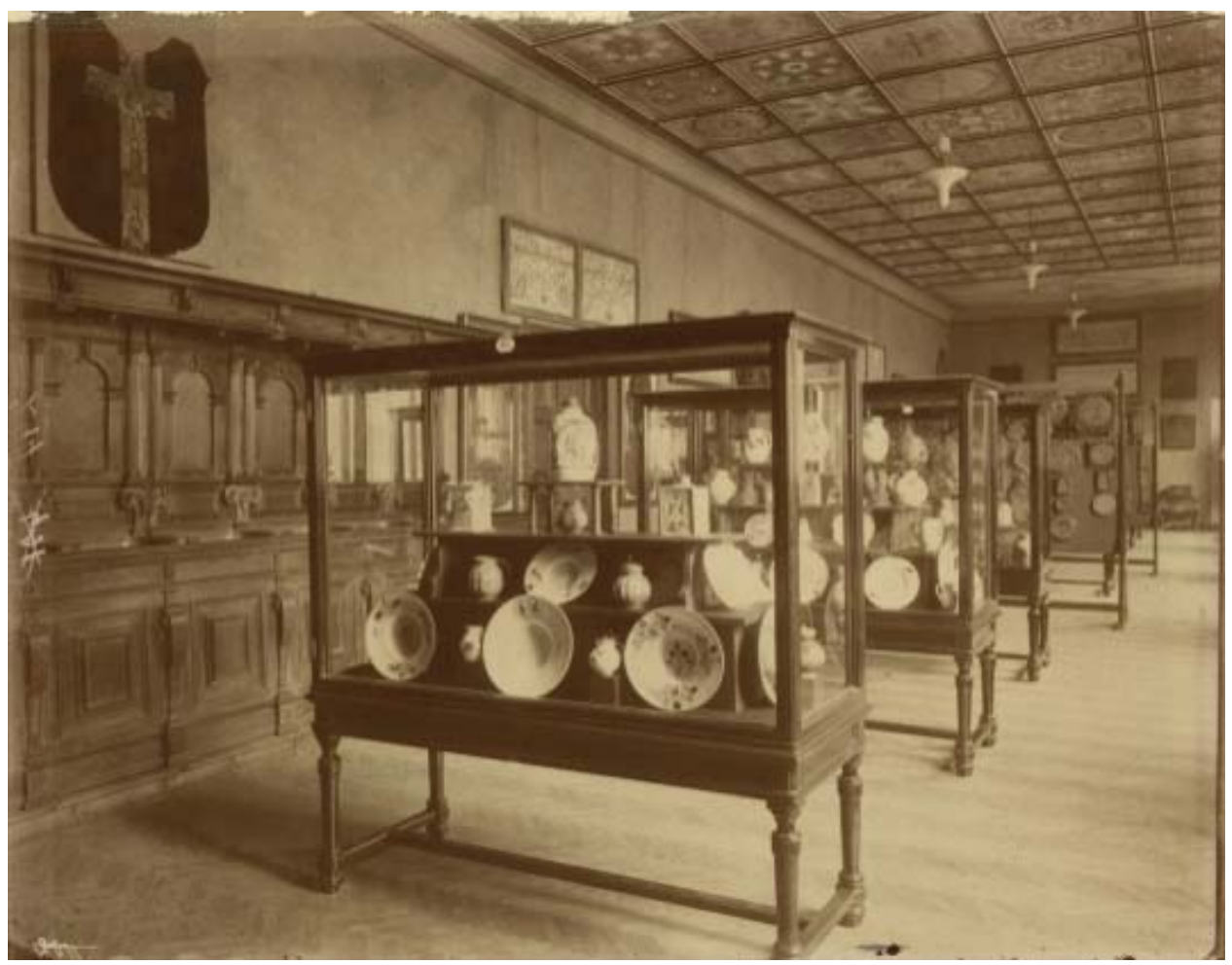

Fig. 1. Exhibition presenting the Museum of Applied Arts' Haban collection in the Hungarian Room, opened in 1897. Museum of Applied Arts' Archiv FLT_25534

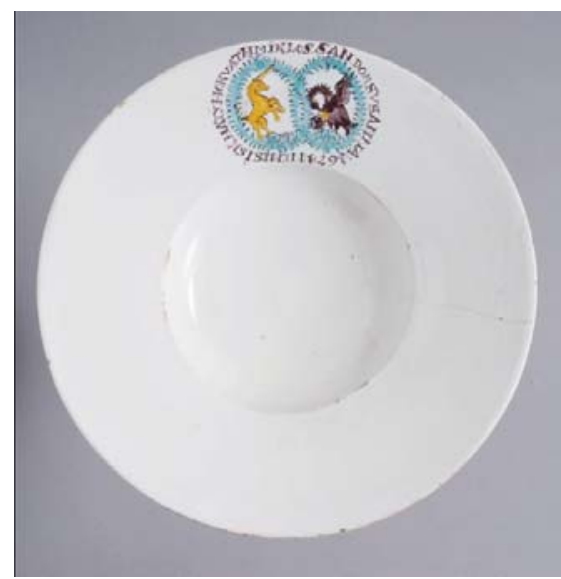

Fig. 2. Dish for the silver wedding anniversary of Noble Miklós Iskházy Horváth

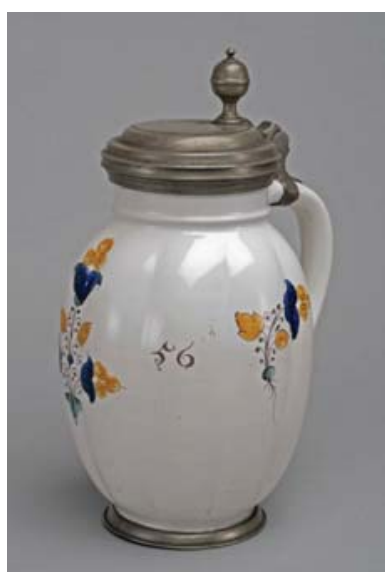

Fig. 3. Fluted jug, 1656. H: 30.1 cm. Inv. n. 2864 and Zsuzsanna Sándor, 1678. D: 37 cm. Inv. n. 2837 


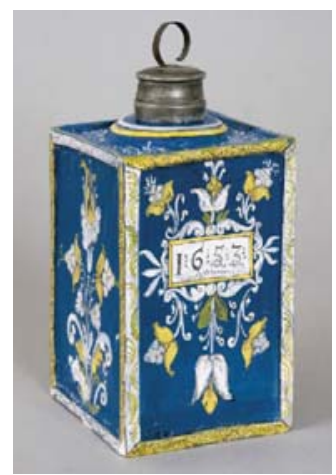

Fig. 4. Rectangular jar with a pewter lid, 1653. H: 23.8 cm. Inv. n. 2845. a-b

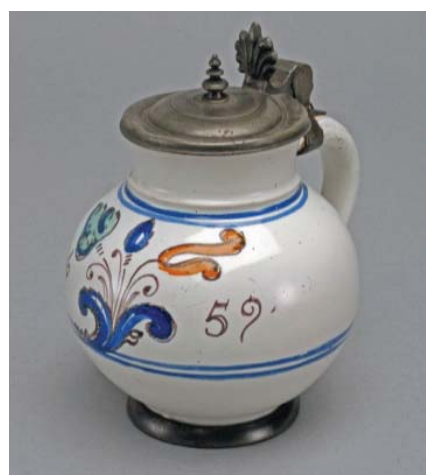

Fig. 5. Jug with a pewter lid, 1650. H: $17.4 \mathrm{~cm}$. Inv. n. 2848

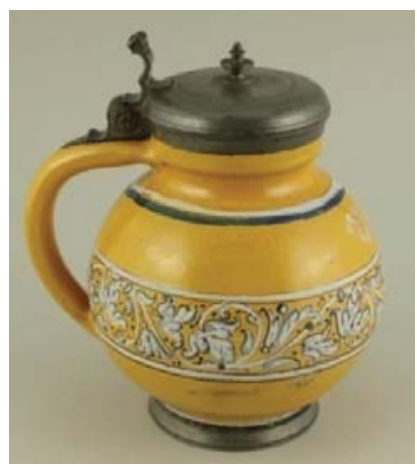

Fig. 6. Jug with a pewter lid, 1659. H: $14.3 \mathrm{~cm}$. Inv. n. 2838
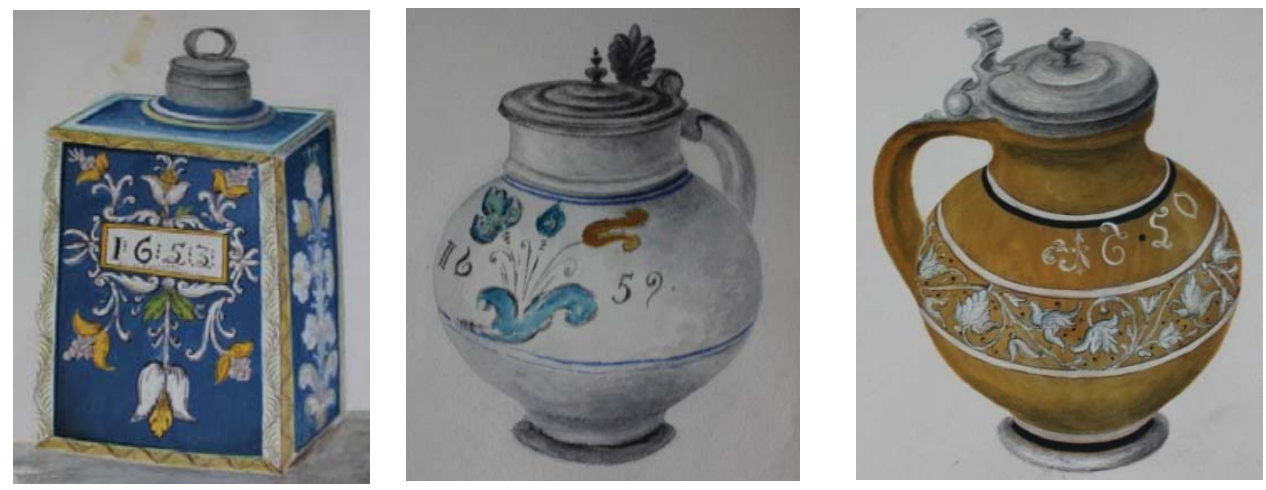

Fig. 7. a, b, c. Water-colours about the Haban pieces from the album of Count Jenö Lázár about the collection. Museum of Applied Arts' Archiv KRTF 19. 


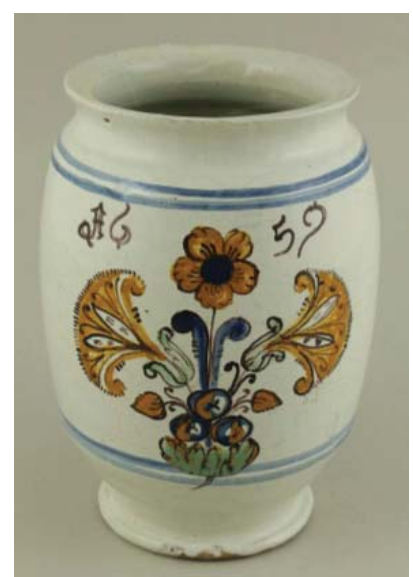

Fig. 8. Albarello, 1659. H: 17.5 cm. Inv. n. 2886.

Purchase from the collection of Baron József Bálintitt in 1889

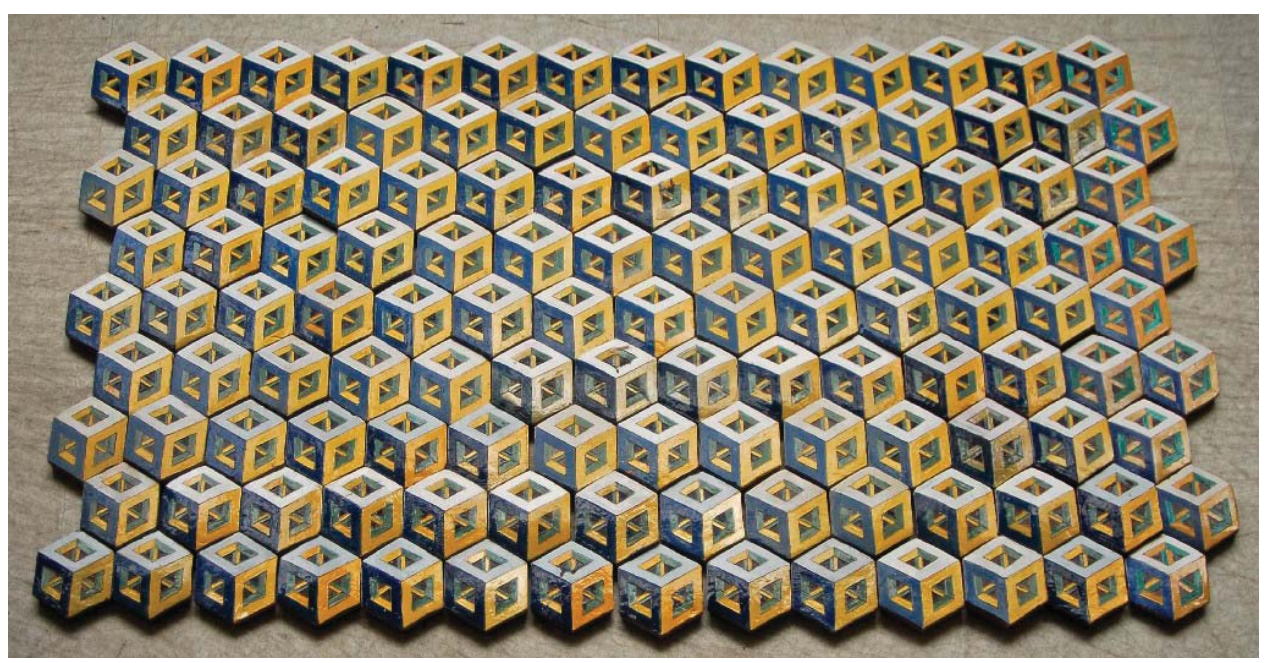

Fig. 9. Hexagonal tiles with axonometric pattern. Size of one tile: $21 \times 21 \times 2.6 \mathrm{~cm}$. Inv. n. 6558 . Purchase from Nagyszombat district chief court in 1909 


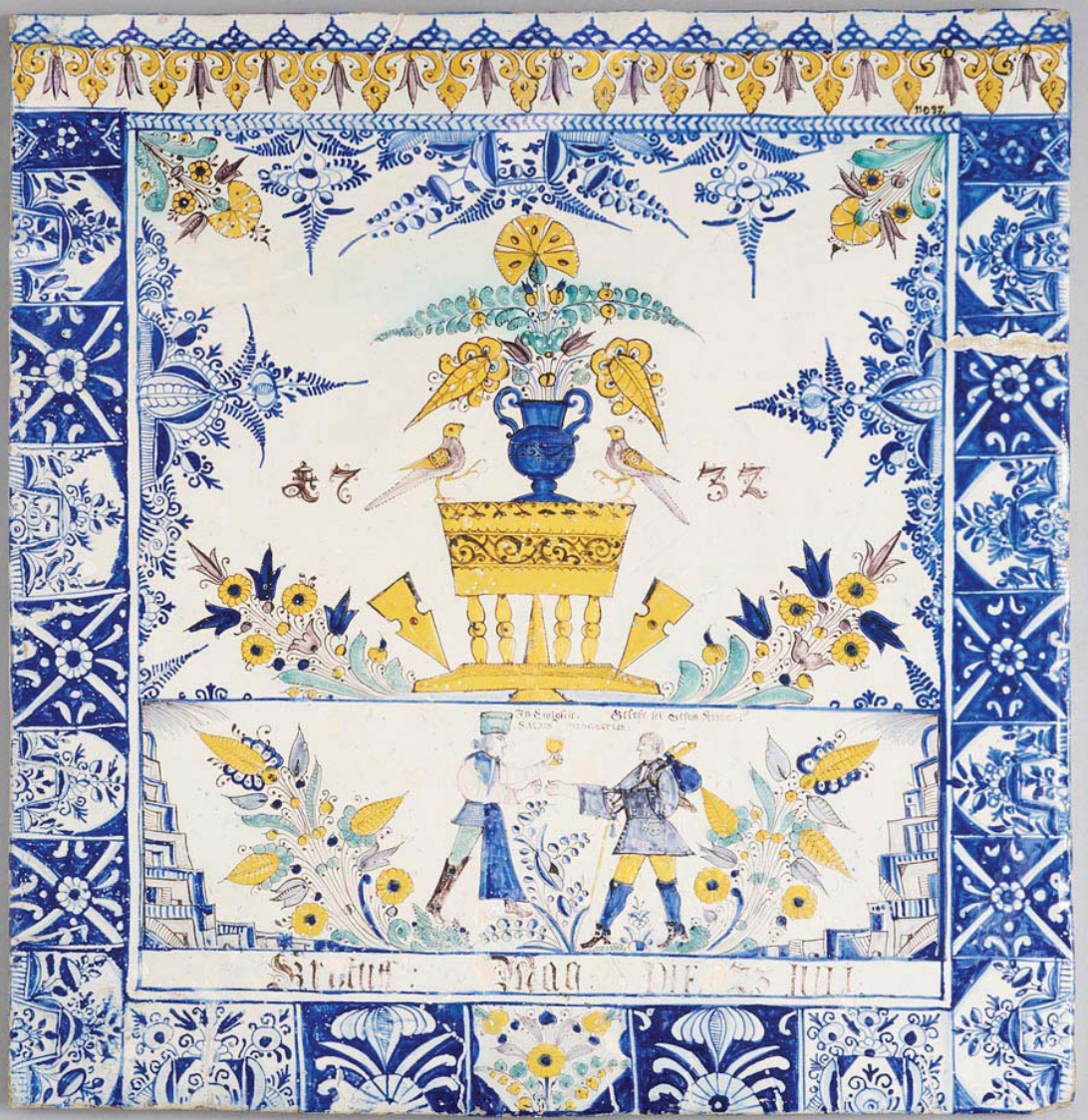

Fig. 10. Potter's guild tablet, 1732. H: 64 cm, L: 60 cm. Inv. n. 11092 


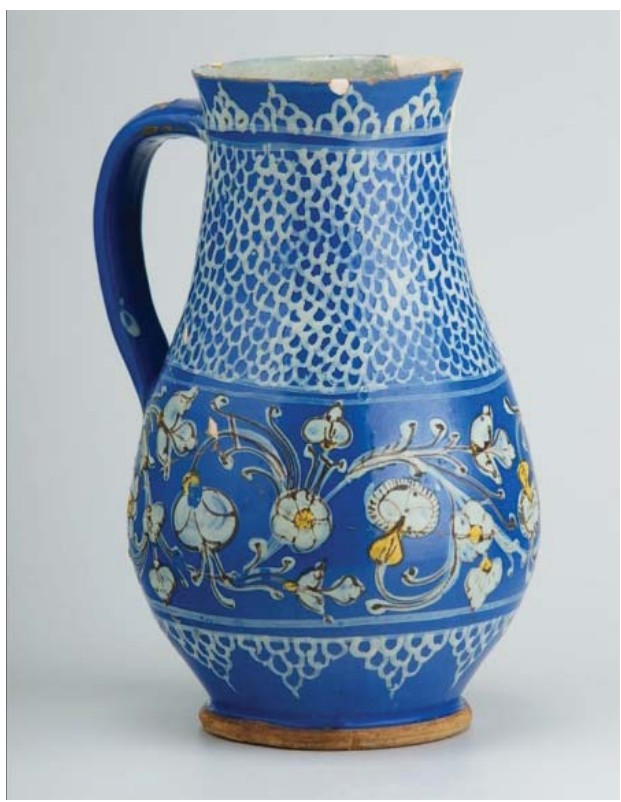

Fig. 11. Jug. 1680-1690. H: 20.5 cm. Inv. n. 14286

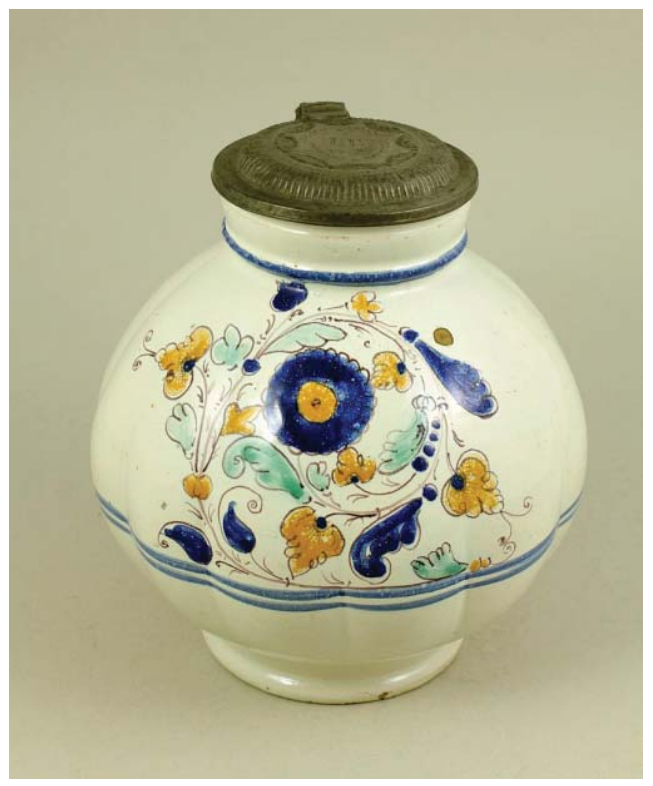

Fig. 12. Fluted, globular jug, 1680-1690. H: 18 cm. Inv. n. 21807 


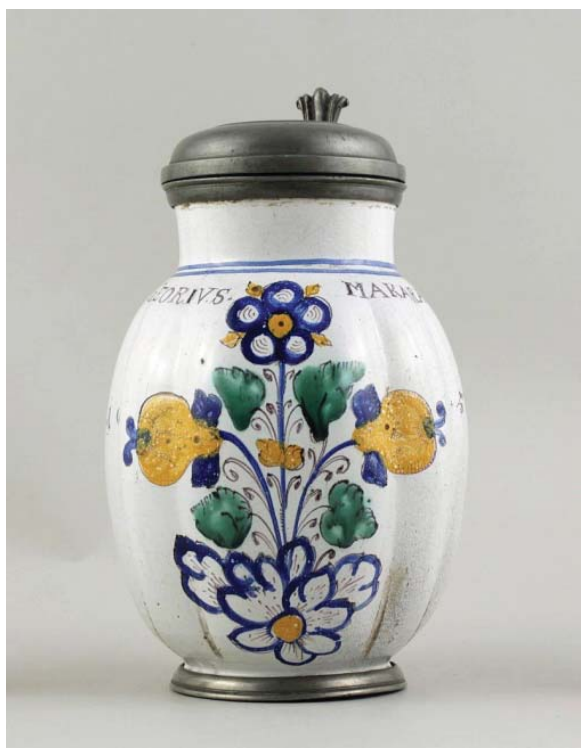

Fig. 13. Fluted jug with the name of GEORIVS MAKARA, 1658. H: $21.3 \mathrm{~cm}$. Inv. n. 69.568 .1

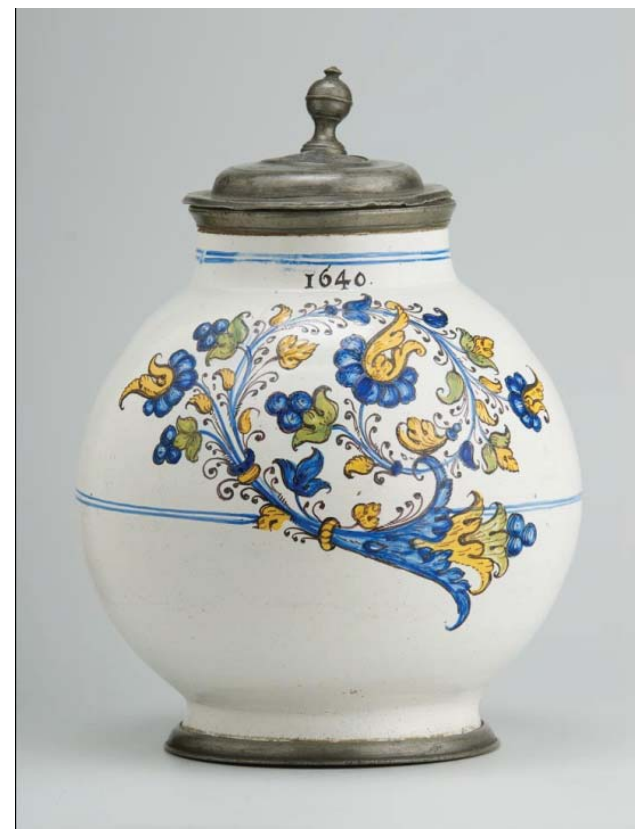

Fig. 14. Jug, 1640. H: 23.5 cm. Inv.n. 72.1 .4 